\title{
PANEL DATA REGRESSION ANALYSIS FOR FACTORS AFFECTING INFANT MORTALITY RATE IN EAST JAVA 2013-2017
}

\author{
Faishal Azhar Wardhana ${ }^{1}$, Rachmah Indawati ${ }^{1}$ \\ ${ }^{1}$ Department of Biostatistics and Population \\ Faculty of Public Health, Airlangga University, Surabaya, Indonesia \\ Alamat korespondensi: Faishal Azhar Wardana \\ Email: faishal.azhar.wardhana-2015@fkm.unair.ac.id
}

\begin{abstract}
The escalating infant mortality rate (IMR) in Indonesia has not been able to fulfill the target of Sustainable Development Goals (SDGs) that restrict the limit of IMR to just 12 of 1,000 live births. According to such fact, this research was designed as the application of panel data regression in an IMR case study of East Java from 2013-2017. Regression panel data enable research in describing cross-sectional and time series information. The variety of data availability in this method were capable of producing a high degree of freedom, allowing it to meet the prerequisites and statistical properties. This method was considered the most suitable one for analyzing the rising IMR. This research was classified as non-reactive research. All regencies/cities in East Java served as this study's population. Data collection included K4 coverage, childbirth assistance, and $\mathrm{KN}$ complete coverage. The result of panel data regression showed a significant connection between K4 coverage $(0.0230)$, childbirth assistance $(p=0.0105)$, and KN complete coverage (0.0205). Adjusted R-Square value was obtained with an amount of $80 \%$, which means that all independent variables were able to explain the dependent one of that value, while the remaining were explained by other factors. This study can provide some suggestions to support IMR in East Java, including handling from the government or related pregnant families to support IMR on an ongoing basis.
\end{abstract}

Keywords: panel data regression, IMR, K4, childbirth assistance, KN complete

\section{INTRODUCTION}

Infant mortality rate (IMR) is the number of deaths per 1,000 live births of children under one year of age. The number of deaths is measured by reference to infant mortality ages 0 to 12 months, compared to 1,000 live births at intervals of a certain period (years) (Central Bureau of Statistics, 2018). IMR is a benchmark for the success of maternal and child health programs. According to a World Health Organization (WHO) report on the Probability of Mortality per 1,000 Live Births Data by Country, Indonesia recorded an IMR of 21.4 out of every 1,000 live births in 2017. This amount is relatively high compared to that of other ASEAN countries (WHO, 2017).
While the survey results indicated a decrease in the IMR, this has not reached the standard of the Sustainable Development Goals (SDGs) program with a limit of 12 deaths per 1,000 live births in 2030. In line with this, East Java - the second most populous province in Indonesia - has a fairly high IMR. In 2005, IMR in this province was 36.65 out of 1,000 live births. In 2012, the number decreased to 28.31. This was followed by a gradual depreciation of IMR at 27.23 in 2013, 25.68 in 2014, 24 in 2015, and 23.6 in 2016 (East Java Provincial Health Office, 2017).

IMR is closely related to several factors including infants, mothers, and health services factors. Infant factors are divided into three categories: early neonatal death (0-7 days), neonatal death (8-28 days), and infant 
death (0-11 months). Some causes of early neonatal death include respiratory problems (37\%), prematurity (34\%), sepsis (12\%), hypothermia $(7 \%)$, blood disorders $(6 \%)$, postmaturation (3\%), and congenital abnormalities (19\%). Neonatal mortality factors include sepsis (20.5\%), congenital abnormalities (19\%), pneumonia (17\%), Respiratory Distress Syndrome (14\%), prematurity (14\%), blood disorders $(3 \%)$, birth injuries (3\%), Tetanus Neonatorum (3\%), nutritional deficiencies (3\%) and Sudden Infant Death Syndrome (3\%). While infant mortality factors include diarrhea (42\%), pneumonia (24\%), meningitis (9\%), gastrointestinal abnormalities (7\%), congenital abnormalities (6\%), sepsis (4\%), and tetanus (3\%) (Ministry of Health Republic of Indonesia, 2015).

The causes of infant death are classified into two types, namely endogenous and exogenous. In endogenous factors, the cause of death comes from factors carried by infants (internal). In exogenous factors, causes of death are influenced by external elements (Rachmah and Purhadi, 2014). Endogenous factors, also called neonatal, are infant deaths that occur in the first month after birth. These are generally triggered by a congenital factor (child) from birth to their parents during pregnancy (conception) which consists of low birth weight (LBW), asphyxia, and congenital abnormalities. Exogenous factors, also called post-neonatal, occur after one month and are influenced by external environmental factors such as health services and maternal factors (Abdiana, 2015; Andriani, Sriatmi, and Jati, 2016).

IMR can be used as a direct reflection of the degree of welfare of the elements of society, especially in the realm of health quality. It also relates to the social status of the baby's (parents) family. In the present study, external (exogenous) factors of K4 coverage, delivery assistance, and complete neonatal visit $(\mathrm{KN})$ were the main variables. $\mathrm{K} 4$ coverage is a term that refers to contact at least four times during pregnancy in the form of a visit by pregnant women to the medical staff responsible for providing antenatal services. The visit does not always mean the process of pregnant women visiting medical services. Visits are flexible and can be medical workers visiting pregnant women in Integrated Healthcare Center or at home (Ministry of Health Republic of Indonesia, 2015).

Medical examinations directly reduce the risk of infant death. Quick steps need to be taken for abnormalities or diseases in pregnant women. Childbirth assistance is an important factor contributing to safe delivery. Help from trained medical personnel and adequate supporting facilities can make delivery assistance work with minimal risk with a high degree of success. In contrast, the delivery of untrained non-medical personnel is often found in rural areas with minimal access to health facilities, or to families with low welfare levels. This leads to insights on health service eligibility standards being not maximally obtained (Ministry of Health Republic of Indonesia, 2015).

Childbirth assistance is a process that begins gradually from stages I to IV. Neonatal visit is a health service from the relevant medical personnel, for neonates in the period of 6 hours to 28 days after birth according to the standard. In general, the scope of this neonatal visit is divided into two parts. The first is the first-time neonatal visit (KN1), which is the first neonatal visit service in 6 to 48 hours of postnatal work area standards. Complete neonatal visit (KN2), as the name implies, has a more complete pattern of time of at least three times, namely once at the age of 6-48 hours, once at 3-7 days, then once at 8-28 days of the standard work area. Infants are affected by the highest risk in the KN1 phase (Pleasse use the Engligh term., 2015).

Based on the description of the problem as a background, this study leads to an analysis to model the IMR influence factor 
by implementing panel data regression analysis. Panel data regression is an analytical method using regression to process data which is a combination of cross sectional (information between units on differences between subjects) and time series (inter-time information that represents changes in the subject of time) (Gujarati, 2015). This method has advantages in the availability of data to be analyzed. Therefore, the application of this method allows researchers to obtain large amounts of data for the sake of statistical test requirements (Sriyana, 2014). Below is the formula for the panel data regression model:

Where

$\mathrm{Y}_{\mathrm{it}} \quad=$ cross sectional units of the $\mathrm{i}$-th for the t-time period.

$\mathrm{B}=$ constant vector $1 \mathrm{x} \mathrm{k}$, where $\mathrm{k}=$ the number of independent variables.

$\mathrm{X}_{\mathrm{it}}=$ shows the observation vector on the independent variable measuring $1 \mathrm{x} \mathrm{k}$.

$\alpha_{\text {it }} \quad=$ intercept is the group / individual effect of the i cross-sectional unit and the $\mathrm{t}$ time period.

$\mathrm{e}_{\mathrm{it}} \quad=$ component error.

$\mathrm{i} \quad=1,2, \ldots, \ldots, \mathrm{n}$.

$\mathrm{t} \quad=1,2, \ldots, \ldots, \mathrm{n}$.

Cross sectional data is information consisting of several variables studied at the same tempo, while the time series includes several variables observed at different times. While the method is frequently applied in the economic field and is rarely encountered in the health sphere, its application is considered appropriate in the case of IMR. This is because this method is able to describe the picture of changes that refer to successive time series. The results of the analysis become stronger thanks to the consideration of time in it. The application of the panel data regression analysis has several benefits in research including increasing degrees of freedom and reducing the possibility of problems from multicollinear data, constructing a series of behavioral and discrimination models, reducing bias, creating more accurate estimates and predictions, providing information that is appropriate to the level of aggregation, and simplifying the procedure of applying cross sectional and time series (Cheng, 2014).

In practice, the panel data regression model has three different approaches, namely Common Effect Model (CEM), Fixed Effect Model (FEM) and Random Effect Model (REM), each of which has its characteristics and differences. In addition to the approach, this research also requires a method in estimating panel data regression. The method consists of the F Test (Chou Test), Hausman Test, and Lagrange Multiplier (LM) Test.

The test focuses on the assumptions of panel data regression. This test was conducted to determine the fulfillment of the BLUE (Best Linear Unlimited Estimator) criteria which made the panel data regression model the best model (Effendi, 2014). Some classic assumptions must be fulfilled as BLUE (Best Linear Unlimited Estimator) criteria can be achieved through the normality test, multicollinearity test, heteroskedesticity test, and autocorrelation test. The final step is testing the panel data regression parameters consisting of the coefficient of determination $\left(\mathrm{R}^{2}\right)$, simultaneous test ( $\mathrm{F}$ test), and partial test (t test).

\section{METHODS}

This is a non-reactive research study as it was conducted by the researchers on research subjects who were unaware or felt that the subject is being studied. The population of this research was 38 regencies/cities in East Java. This research was carried out by taking secondary data, related to the IMR influence factor, in the East Java Provincial Health Office. It took at least 8 months to cover the process of preparing proposals, requesting and analyzing data, and compiling the results of research reports. It has 
obtained information passing the ethical review from the $\mathrm{FKG}$ ethics commission number 360 / HRECC.FODM / VI / 2019.

The variable in this study, IMR, as mentioned earlier, is a dependent variable. Independent variables consisted of three exogenous factors including $\mathrm{K} 4$ coverage, delivery assistance, and complete $\mathrm{KN}$ coverage. The data used were secondary data obtained from the Health Profile of East Java Province 2014-2018 which has been published. Data collection was performed by recording the secondary data needed. Data analysis of IMR influence factors was conducted descriptively and inferentially. Descriptive statistics used include minimum, maximum, and mean of the dependent variable (IMR) and independent variables (K4 coverage, delivery assistance, and $\mathrm{KN}$ coverage complete). This step aimed to represent the sample descriptively.

Inferential statistics were used to analyze the relationship between independent variables and dependent variables. This used panel data regression analysis. The stages of panel data regression analysis in this study are as follows:

\section{Determination of Estimation Model}

Panel data regression approach consisted of three models: common effect model, fixed effect model, and random effect model. The common effect model approach is relatively simple because it assumes that the data behavior is the same at various times. While in the fixed effect model, differences between individuals are assumed to be accumulated from differences in their intercepts. In its application, this model uses the dummy variable technique to obtain differences in intercepts. In the random effect model, the panel data where the interruption variables allow to be interconnected between individuals and time will be estimated. This approach accommodates the intercept differences in the error terms of each data.

\section{Determination of Estimation Method}

In line with the use of estimation models, there are three test methods. The first test method is the Chou test which is used to determine the best common effect model or fixed effect model. The second is the Hausman test which is a statistical test to determine which one is better between the fixed effect model or the random effect model. The last is the Lagrange multiplier test that works to find out if the random effect model is better than the common effect model.

\section{Implementation of Panel Data Regression Assumption Test}

Panel data regression analysis has several classic assumptions to be fulfilled in order to fulfill the Best Linear Unlimited Estimator (BLUE) rule on the estimation produced. The assumptions are normality, multicollinearity, heteroscedasticity, and autocorrelation. If the BLUE rules are not fulfilled, the estimators produced will differ greatly from reality. Deleting data that has residual outliers or implementing variable transformations is a solution if there is one unfulfilled assumption.

\section{Data Interpretation}

The final step is to carry out the statistical tests needed to test the truth of the hypothesis to find out the coefficients of each independent variable. The intended statistical tests include R Square, F Test, and Partial t Test. This test used an alpha value of 0.05 which means the research had an error limit of $5 \%$ or 0.05 set as a reference. This means that it is expected to produce an error of less than 5 times out of 100 attempts.

The first step of this research flow was to process the independent and dependent variables with descriptive statistical analysis. The second step was to regress panel data using the three estimation model methods described previously. Next, the estimation 
method was carried out by applying the necessary test steps. The results of the test were then analyzed using a regression assumption test to detect data problems and fulfillment of BLUE. When all the regression assumptions had been fulfilled in the last step of this study, the interpretation of the results was done. However, if all assumptions were not fulfilled, elimination of data with outliers is absolutely necessary. After elimination, the steps were repeated from number 2 until the findings had no problems and met the BLUE rules.

\section{RESULT}

The output of this study was divided into several categories. First was the identification of IMR characteristics in East Java from 2013 to 2017 as the dependent variable. This was followed by $\mathrm{K} 4$ coverage, delivery assistance, and complete $\mathrm{KN}$ coverage as independent variables. The dependent variable and the independent variables were processed by descriptive statistical analysis.

\section{General description of IMR in the province of East Java}

In the research carried out, the highest IMR in East Java in 2013 to 2017 occurred in Probolinggo City with an average of 24.30 per thousand live births. The lowest IMR was in Sumenep Regency with an average of 3.47 per thousand live births.

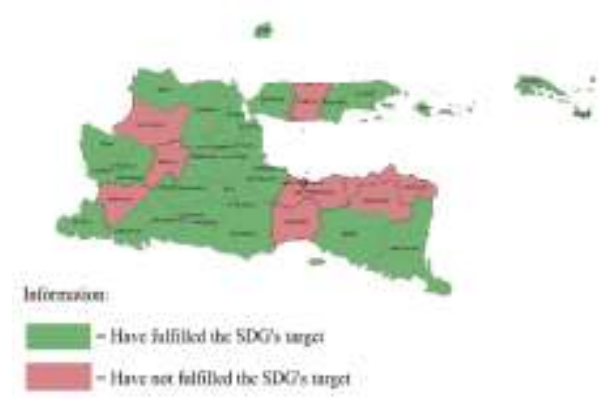

Figure 1. Overview of IMR in East Java Province in 2013-2017
Based on Figure 1, there were several districts/cities that had not fulfilled the SDG target, which was to reduce the IMR by 12 per thousand live births. Regencies/cities that had not yet reached the SDG target include Bojonegoro, Bondowoso, Probolinggo, Lumajang, Nganjuk, Kab. Ponorogo, Sampang, Situbondo, and Probolinggo.

\section{Overview of the Factors Influencing IMR K4 Coverage}

The highest K4 coverage in East Java in 2013-2017 was in Surabaya City with an average value of 98.35 . The lowest K4 coverage in the same province and year was in Jember Regency with an average value of 78.75. Based on Figure 2, one regency, Jember had not fulfilled the Indonesian Ministry of Health's strategic plan targets for 2015-2019, especially for a K4 coverage of $80 \%$. Several regencies/cities that had not fulfilled the Indonesian Ministry of Health's strategic plan targets for 2015-2019.

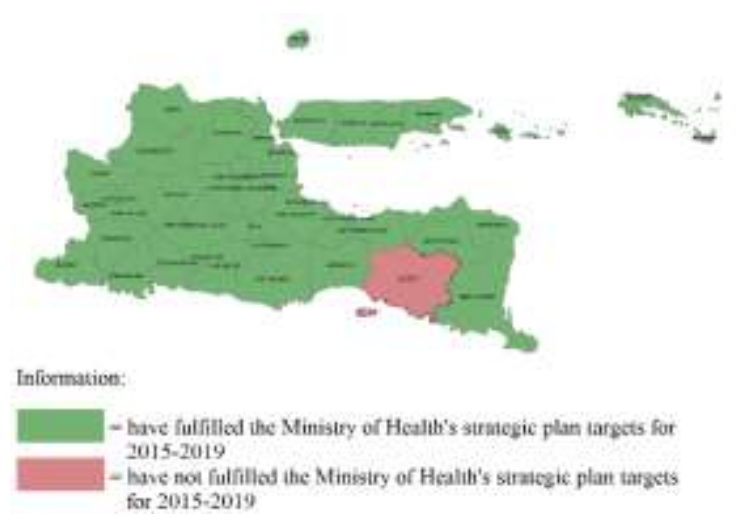

Figure 2. Overview of K4 Coverage in East Java in 2013-2017

\section{Delivery assistance}

The highest provision of delivery assistance by medical personnel in East Java Province in 2013-2017 was occupied by the Sidoarjo Regency with an average value of 98.96. The lowest was occupied by the Pacitan District with an average value of 86.32. Based 
on Figure 3, in 2013-2017, all districts/cities in East Java had not fulfilled the Minimum Service Standards (MSS) target, especially for delivery assistance by health workers by $100 \%$.

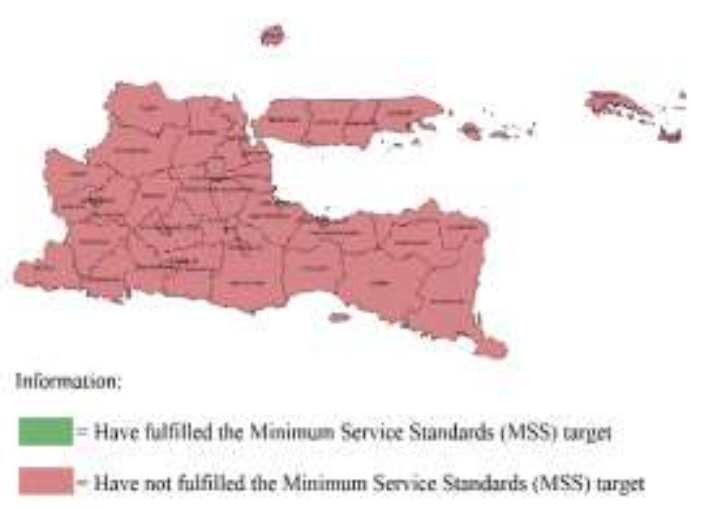

Figure 3. Overview of Delivery Assistance in East Java in 2013-2017

\section{Complete $\mathrm{KN}$ coverage}

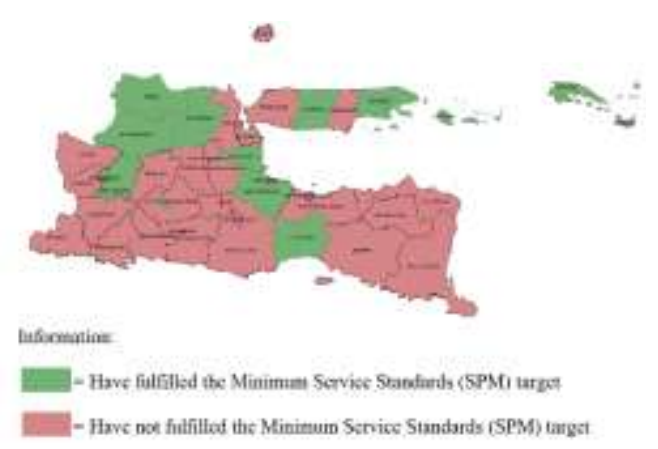

Figure 4. Overview of Complete $\mathrm{KN}$ Coverage in East Java in 20132017

In the research carried out, the district with the highest complete KN coverage in East Java in 2013-2017 was the Sumenep Regency with an average value of 100 . While the area with the lowest complete $\mathrm{KN}$ coverage in the same year was Blitar City with an average value of 89.55. Based on Figure 4, there were a number of districts/cities that had fulfilled the MSS target, specifically for full $\mathrm{KN}$ coverage of $100 \%$. Regencies/cities that had achieved the SPM target include Kab. Lumajang, Kab. Pasuruan, Kab. Sidoarjo, Kab. Bojonegoro, Kab. Tuban, Kab. Lamongan, Kab. Sampang, Kab. Sumenep, Kota Mojokerto and Kota Madiun.

\section{Panel Data Regression Analysis}

There were three different approaches, each of which has advantages and disadvantages. The three models used were the common effect model, fixed effect model and random effect model. The best model was obtained after passing the Chou test (CEM or FEM), Hausman test (FEM or REM), and Lagrange Multiplier test (CEM or REM).

The second step was determining the estimation model to find the best model from the three choices. Next was determining the estimation model.

\section{Chou Test}

In Table 1, the determination of the estimation model refers to the cross section $\mathrm{F}$ probability value. If it is lower than (0.05), then $\mathrm{H}_{0}$ is rejected, which means FEM is the best model. Subsequent testing used the Hausman Test to determine the best model between FEM or REM.

Table 1. Determination of Estimated Model of 38 Districts/Cities of East Java

\begin{tabular}{lcc}
\hline \multicolumn{1}{c}{ Chou Test } & & \\
\hline \multicolumn{1}{c}{ Effect Test } & Statistic & Prob. \\
\hline Cross section F & 1.542628 & 0.0372 \\
\hline $\begin{array}{l}\text { Cross section } \\
\text { Chi-square }\end{array}$ & 61.973126 & 0.0062 \\
\hline \multicolumn{1}{c}{ Hausman Test } & & \\
\hline \multicolumn{1}{c}{ Test Summary } & $\begin{array}{c}\text { Chi-Sq } \\
\text { Statistic }\end{array}$ & Prob. \\
\hline $\begin{array}{l}\text { Cross section } \\
\text { Random }\end{array}$ & 14.204907 & 0,0067 \\
\hline
\end{tabular}




\section{Hausman Test}

In Table 1 , if the random cross section probability value is lower than $\alpha(0.05)$, then $\mathrm{H}_{0}$ is rejected, which means FEM is the best model. If the best model is FEM from the Hausman test, it does not need to be tested using the Lagrange multiplier test. This continued in the third phase of the classical regression assumption test. The following is the description of the classical regression assumption test.

\section{Multicollinearity Test}

Based on the description in Table 2, a summary of the classical regression assumptions, each variable had an $\mathrm{R}^{2}$ value of less than $|0.8|$. In conclusion, the regression model did not experience problems in the multicollinearity test.

\section{Autocorrelation Test}

The Durbin-Watson value obtained from the fixed effect model was 2.308130. Serial correlation on the data did not occur because the results of the test values were close to two.

\section{Heteroscedasticity Test}

Based on the description in Table 2, a summary of the classical regression assumptions found that each independent variable had a significance value of less than $\alpha$ (0.05). Therefore, the regression model did not experience heteroscedesticity problems.

Table 2. Summary of Classical Regression Assumptions of 38 Districts/Cities in East Java

\begin{tabular}{|c|c|c|c|}
\hline \multicolumn{4}{|c|}{ Multicollinearity Test } \\
\hline \multicolumn{2}{|c|}{ Delivery Assistance } & $\begin{array}{c}\text { Complete KN } \\
\text { Coverage }\end{array}$ & K4 Coverage \\
\hline Delivery Assistance & 1 & 0.73918 & 0.7868 \\
\hline Complete KN Coverage & 0.7391 & 1 & 0.5892 \\
\hline K4 Coverage & 0.7868 & 0.5892 & 1 \\
\hline \multicolumn{4}{|c|}{ Heteroscedasticity Test } \\
\hline Variable & & & Note \\
\hline K4 & 0.2639 & & No Heterokedesticity \\
\hline Delivery Assistance & 0.2803 & & No Heterokedesticity \\
\hline Complete KN & 0.5342 & & No Heterokedesticity \\
\hline \multicolumn{4}{|c|}{ Autocorrelation and Normality Test } \\
\hline Test & Prob. & & Note \\
\hline Durbin-Watson & 2,308130 & & $\begin{array}{c}\text { No autocorrelation } \\
\text { occurred }\end{array}$ \\
\hline Normality & 0.0000 & & $\begin{array}{c}\text { No autocorrelation } \\
\text { occurred }\end{array}$ \\
\hline
\end{tabular}

\section{Normality Test}

The last test used a histogram to test the normality problem by looking at the probability value. If the probability value is less than 0.05 then the normality problem occurs. Conversely, if the probability value is more than 0.05 , then the normality problem does not occur. Probability values are shown in Table 2.

Based on these tests, the probability of 0.000 is lower than the value of $\alpha(0.05)$; 
therefore, there was a problem with the panel data regression model. The solution to the problem of normality was deletion of data that were thought to have a residual outlier value by using a box plot.

After the outlier test was carried out using a box plot, there were at least six districts/cities with outlier data including Gresik, Lamongan, Madiun, Nganjuk, Sampang, and Tulungagung. Only Nganjuk had an extreme outlier that had the potential to cause greater problems in this study.

The second step was determining the estimation model to find the best model from the three choices. The following are the test results.

Table 3. Determination of Estimation Model 37 of Districts/Cities in East Java

\begin{tabular}{lcc}
\hline \multicolumn{3}{c}{ Chou Test } \\
\hline \multicolumn{1}{c}{ Effect Test } & Statistic & Prob. \\
\hline Cross section F & 17.54 & 0.000 \\
\hline $\begin{array}{l}\text { Cross section } \\
\text { Chi-square }\end{array}$ & 311.48 & 0.000 \\
\hline \multicolumn{3}{c}{ Hausman Test } \\
Test Summary & $\begin{array}{c}\text { Chi-Sq } \\
\text { Statistic }\end{array}$ & Prob. \\
\hline $\begin{array}{l}\text { Cross section } \\
\text { Random }\end{array}$ & 12.480109 & 0.0141 \\
\hline
\end{tabular}

\section{Chou Test}

The cross-section $\mathrm{F}$ probability value in Table 3 is lower than $\alpha(0.05)$, meaning $\mathrm{H}_{0}$ is rejected. This means that the fixed effect model is the best model. The next test was the Hausman Test to determine whether the best model was the fixed effect model or random effect model.

\section{Hausman Test}

The random cross-section probability value in Table 3 is lower than $\alpha(0.05)$; therefore, $\mathrm{H}_{0}$ is rejected and the fixed effect model is the best model. The third phase was the classical regression assumption test.

\section{Multicollinearity Test}

Based on the description in Table 4, a summary of the classical regression assumptions shows that each independent variable had no $\mathrm{R}^{2}$ value of less than $|0.8|$; therefore, the regression model did not experience Multicollinearity problems.

\section{Autocorrelation Test}

Based on Table 4 summarizing classical regression assumptions, the DurbinWatson value obtained from the fixed effect model was 1.578842. This represents the results of this test. Serial correlation on the data did not occur because the results of the test values approached number 2 .

\section{Heteroscedasticity Test}

In Table 4, a summary of the classical regression assumptions of 37 regencies/cities in East Java shows that each variable had a significance value of less than $\alpha$ (0.05); therefore, the regression model did not experience heterokedesticity problems.

\section{Normality Test}

The last test was a histogram graph to test normality by examining the probability value. Based on Table 4, a summary of the classical regression assumptions shows a probability value of 0.1873 , which is higher than the value of $\alpha(0.05)$; therefore, there was no normality problem in the panel data regression model. 
Table 4. Summary of Classical Regression Assumptions 37 Regencies/Cities of East Java

\begin{tabular}{|c|c|c|c|}
\hline \multicolumn{4}{|c|}{ Multicollinearity Test } \\
\hline & $\begin{array}{c}\text { Delivery } \\
\text { Assistance }\end{array}$ & $\begin{array}{c}\text { Complete KN } \\
\text { coverage }\end{array}$ & K4 Coverage \\
\hline Delivery Assistance & 1 & 0.7393 & 0.7836 \\
\hline Complete $\mathrm{KN}$ coverage & 0.7393 & 1 & 0.5776 \\
\hline K4 Coverage & 0.7836 & 0.5776 & 1 \\
\hline \multicolumn{4}{|c|}{ Heteroscedasticity Test } \\
\hline Variable & Prob. & \multicolumn{2}{|c|}{ Note } \\
\hline K4 & 0.8136 & \multicolumn{2}{|c|}{ No Heterokedesticity } \\
\hline Delivery Assistance & 0.1031 & \multicolumn{2}{|c|}{ No Heterokedesticity } \\
\hline Complete KN & 0.1611 & \multicolumn{2}{|c|}{ No Heterokedesticity } \\
\hline \multicolumn{4}{|c|}{ Autocorrelation and Normality Test } \\
\hline Test & Prob. & \multicolumn{2}{|c|}{ Note } \\
\hline Durbin-Watson & 1.578842 & \multicolumn{2}{|c|}{ No autocorrelation } \\
\hline Normality & 0.1873 & \multicolumn{2}{|c|}{ No normality problems } \\
\hline
\end{tabular}

After all the assumptions of the regression were fulfilled, the next step was to perform panel data estimation. The steps in panel data regression analysis are as follows:

\section{Adjusted R-Square}

Based on Table 5 on the summary estimation of panel data regression parameters, the adjusted R-squared value of 0.806744 indicates that as much as $80 \%$ of the dependent variables could be explained by the independent variable, while the rest could be explained by other variables outside the research data.

\section{Simultaneous Test (F Test)}

In Table 5 on the summary of parameter estimates, the Prob (F-statistic) value of 0.0000 is lower than $\alpha(0.05)$, meaning $\mathrm{H}_{0}$ is rejected. It was concluded that there was at least one independent variable that affected the dependent variable.

\section{Partial Test (t test)}

Based on Table 5 on the summary estimation of panel data regression parameters, the $\mathrm{p}$-value of the $\mathrm{K} 4$ variable with a significance level of $95 \%$ was 0.0230 . This is lower than $\alpha(0.05)$. Thus, $\mathrm{H}_{0}$ is rejected, which means that this variable had a significant effect on IMR. For the delivery assistance variable, the p-value with a significance level of $95 \%$ was 0.0105 . This is lower than $\alpha(0.05)$. Thus, $\mathrm{H}_{0}$ is rejected, which means that this variable had a significant effect on IMR.

In the complete $\mathrm{KN}$ variable, the $\mathrm{p}$ value with a significance level of $95 \%$ was 0.0205 , which is lower than $\alpha(0.05)$. Thus, $\mathrm{H}_{0}$ is rejected, which means that this variable had a significant effect on IMR.

Table 5. Summary of Panel Data Regression Estimation

\begin{tabular}{lcc}
\hline \multicolumn{1}{c}{ Variable } & Coefficient & Prob. \\
\hline Constant & 26.72075 & 0.0006 \\
\hline K4 & -0.274392 & 0.0230 \\
\hline Delivery assistance & 0.318107 & 0.0105 \\
\hline Complete KN & -0.222113 & 0.0205 \\
\hline Adjusted R-squared & \multicolumn{2}{c}{0.806744} \\
\hline
\end{tabular}

\section{Panel Data Regression Model}

Table 5 is a summary estimation of panel data regression parameters, the 
constant value, and each parameter of the independent variable, including its effect on IMR (positive or negative). With this, the general equation is as follows:

$\mathrm{Y}_{\text {it }}=26.72075-0.274392 \mathrm{x}_{1 \mathrm{it}}+0.318107 \mathrm{x}_{2 \mathrm{it}}-$ $0.222113 \mathrm{x}_{3 \mathrm{it}}$

The period effect was inserted into the equation by adding it to a constant with each period of the period effects' coefficient and is described as follows.

Table 6. Panel Data Regression Model

\begin{tabular}{|c|c|}
\hline Year & $\begin{array}{c}\text { Panel Data Regression } \\
\text { Model }\end{array}$ \\
\hline 2013 & $\begin{array}{l}(26.72075+0.584299)- \\
0.274392 x_{1 i t}+0.318107 x_{2 i t}- \\
0.222113 x_{3 i t}\end{array}$ \\
\hline 2014 & $\begin{array}{l}(26.72075+0.571820)- \\
0.274392 x_{1 i t}+0.318107 x_{2 i t}- \\
0.222113 x_{3 i t}\end{array}$ \\
\hline 2015 & $\begin{array}{l}(26.72075+0.891359)- \\
0.274392 x_{1 i t}+0.318107 x_{2 i t}- \\
0.222113 x_{3 i t}\end{array}$ \\
\hline 2016 & $\begin{array}{l}(26.72075+0.535359)- \\
0.274392 x_{1 i t}+0.318107 x_{2 i t}- \\
0.222113 x_{3 i t}\end{array}$ \\
\hline 2017 & $\begin{array}{l}(26.72075+1.512119)- \\
0.274392 x_{1 i t}+0.318107 x_{2 i t}- \\
0.222113 x_{3 i t}\end{array}$ \\
\hline
\end{tabular}

In the equation found in Table 6 , the variable of childbirth assistance had a positive effect on IMR. K4 and KN complete negatively affected the IMR, hence, their increase will suppress the IMR.

\section{DISCUSSION}

In general, IMR in East Java has gradually decreased. This is an indication of an increase in the degree of public health. Of course, this success also comes from the success of related institutions. This is especially true for the East Java Provincial Health Office in carrying out various programs that have been carried out comprehensively and synergistically, from medical policy makers to technical implementers.

The regency/city with the highest IMR was Probolinggo City, while the lowest was Sumenep. Descriptively, the factors that influenced the high IMR in Probolinggo City were delivery assistance at the level of 18 of 38 districts/cities, complete $\mathrm{KN}$ with a ranking of 30 out of 38 districts/cities, and $\mathrm{K} 4$ with a rank of 8 out of 38 districts/cities in East Java.

Factors that influenced the low IMR in the Sumenep Regency were delivery assistance at level 10 of 38 districts/cities, complete $\mathrm{KN}$ with rank 1 out of 38 districts/cities, and K4 with rank 13 out of 38 districts/cities in East Java. The most significant difference between the two areas was in the complete $\mathrm{KN}$ coverage figures.

This study did not meet one of the four classical assumptions, namely the normality test. The solution to overcome the problem of normality was to eliminate data considered to have the highest outliers. After eliminating the data, a retest was performed from the beginning. Upon the completion of these steps, the results of the assumption of normality could be fulfilled, hence test could continue.

There are several studies that raise the same issue. Referring to the first study, the issue raised was the relationship between medical help and IMR. It states that this variable has a negative effect on IMR. This means that the higher the delivery with medical help, the lower the IMR, and vice versa. In this study, the value of the regression coefficient of medical assistance was -0.516 , which means an increase of $1 \%$ will result in a decrease of 0.516 in every 1,000 live births (Warsita and Marhaeni, 2015).

In the second study, $\mathrm{KN}$ variable had a big effect on IMR. Fisher's exact test was used in this study with a p-value of 0.000 as 
an indication of the relationship between the two. An OR value of 280.5 means that babies without $\mathrm{KN}$ had a risk of death of 280.5 times compared with those who had KN (Tyas and Notobroto, 2014).

The third study used $\mathrm{K} 4$ as the object of research. This research yielded |Zcount of $|-3.88|$. The |Zcount | was compared with $\mathrm{Z}(\alpha / 2) 1.96$, which also concluded that there was a relationship between $\mathrm{K} 4$ and IMR. The estimated value in this study was exp (0.017), which means that with every additional $1 \%$ of $\mathrm{K} 4$, IMR will decrease by 0.9831 from the overall mean if there are no other variables involved (Rachmah and Purhadi, 2014).

The latest study was on the analysis of regression data in the IMR case in East Java between 2008-2013. A number of factors were found to partially influence significantly on IMR. This included GRDP per capita, health facilities at the delivery level with medical personnel, and the level of women's education (Khoirunnisa, 2015).

\section{CONCLUSION}

Based on the overall stages, the best model that can be applied to the results of the panel data regression analysis of this study was the fixed effects model, with the acquisition of the model equation in general as follows:

$$
\begin{aligned}
\mathrm{Y}_{\mathrm{it}}= & 26.72075-0.274392 \mathrm{x}_{1 \mathrm{it}}+0.318107 \mathrm{x}_{2 \mathrm{it}} \\
& -0.222113 \mathrm{x}_{3 \mathrm{it}}
\end{aligned}
$$

Factors affecting IMR in 38 districts/cities in East Java between 20132017 were factors that had a significant relationship including $\mathrm{K} 4$ coverage, delivery assistance by medical personnel, as well as full $\mathrm{KN}$ coverage. For a general description of IMR in 38 districts cities in East Java between 2013-2017, the highest average IMR was 24.30 per thousand live births and the lowest was 3.47 per thousand live births. The highest K4 coverage was 93.35 and the lowest was 78.73. The highest rate of delivery assistance was 98.96 and the lowest was 86.32. The highest average complete KN coverage was 100 and the lowest was 89.55.

Some suggestions for suppressing IMR in East Java were given according to the results of the study. The first suggestion is health services, especially from health centers. As the frontline in the implementation and delivery of medical services, health centers are expected to be able to raise awareness of the importance of pregnancy visits, delivery assistance by competent health workers, and neonatal visits as an effort to suppress IMR. This strengthening can be in the form of counseling and even utilizing the current openness of information media, such as public service announcements. The second suggestion is that families, especially husbands, should be able to provide support for the pregnant mother in carrying out the stages of routine pregnancy visits. This is intended as a preventive and monitoring measure for the long-term safety of mothers and babies. In addition, the family must provide motivation for mothers who have given birth during a complete neonatal visit because the baby is vulnerable to death during the neonatal phase.

\section{REFERENCES}

Abdiana, 2015. Determinan Kematian Bayi di Kota Payakumbuh. Jurnal kesehatan masyarakat Andalas, 9(2), pp.88-92.

Andriani, A., Sriatmi, A. and Jati, S., 2016. Faktor Penyebab Kematian Bayi di Wilayah Kerja Puskesmas Ngombol Kabupaten Purworejo (Studi Kasus Tahun 2015). Jurnal kesehatan masyarakat, 4(1), pp.23-33.

Cheng, H., 2014. Analysis of Panel Data second edition. New York: Cambridge University Press. 
East Java Provincial Health Office, 2017. Profil Kesehatan Provinsi Jawa Timur 2016. Surabaya: East Java Provincial Health Office.

Effendi, H.S., 2014. Penerapan Regresi Panel dalam Mengetahui Pengaruh profitabilitas terhadap Dividend Payout Ratio (DPR) pada Perusahaan Manufaktur. Jurnal Mahasiswa Statistik, 2(6), pp.449-452.

Gujarati, 2015. Econometrics by Example Second Edition. United Kingdom: Palgrave.

Khoirunnisa, F., 2015. Determinan Angka Kematian Bayi di Kabupaten/Kota Provinsi Jawa Timur. Universitas Airlangga.

Ministry of Health Republic of Indonesia, 2015. Profil Kesehatan Indonesia 2015. Jakarta: Indonesian Ministry of Health.

Rachmah, N.F. and Purhadi, 2014.
Pemodelan Jumlah Kematian Ibu dan Jumlah Kematian Bayi di Provinsi Jawa Timur Menggunakan Bivariate Poisson Regression. Jurnal Sains dan Seni Pomits, 3(2), pp.194-199.

Sriyana, J., 2014. Metode Regresi Data Panel. Yogyakarta: Ekonisia.

Tyas, S.C. and Notobroto, H.B., 2014. Analisis Hubungan Kunjungan Neonatal, Asfik-sia dan BBLR dengan Kematian Neonatal. Jurnal Biometrika dan Kependudukan, 3(2), pp.168-174.

Warsita, W.M. and Marhaeni, A., 2015. Pengaruh PDRB Per Kapita, Pendidikan Ibu, dan Pelayanan Kesehatan Terhadap Angka Kematian Bayi di Provinsi Bali. PIRAMIDA, 11(1), pp.35-40.

WHO, 2017. Infant mortality (Probability of dying per 1000 live births Data by country). [online] 